DOI: https://doi.org/10.24127/ajpm.v8i3.2312

\title{
EFEKTIVITAS STUDENT TEAMS ACHIEVEMENT DIVISION DITINJAU DARI PRESTASI BELAJAR MATEMATIKA
}

\author{
Adinda Vrihastien", Sri Adi Widodo ${ }^{2 *}$, Annis Deshinta ${ }^{3}$ \\ ${ }^{1,2,3}$ Pendidikan Matematika, Universitas Sarjanawiyata Tamansiswa \\ E-mail: $\quad$ sriadi@ustjogja.ac.id ${ }^{2 *}$
}

Received 18 September 2019; Received in revised form 11 November 2019; Accepted 26 November 2019

\begin{abstract}
Abstrak
Penelitian ini bertujuan untuk mengetahui efektivitas model pembelajaran kooperatif Student Team Achievement Divisions dalam hal prestasi matematika. Jenis penelitian ini adalah penelitian eksperimen dengan populasi siswa kelas VIII SMP N 3 Bantul yang diambil dengan menggunakan teknik cluster random sampling. instrumen penelitian menggunakan tes pada subjek kesempatan. Teknik analisis data menggunakan uji-t dengan mempertimbangkan uji asumsi untuk tes. Dari hasil penelitian dapat disimpulkan bahwa pada prestasi belajar, model Student Teams Achievement Division lebih efektif digunakan dalam pembelajaran matematika dalam peluang materi jika dibandingkan dengan model pembelajaran langsung. terkait dengan hasil ini, Model Student Team Achievement Divisions dapat digunakan sebagai alternatif dalam belajar matematika, terutama dalam peluang materi.
\end{abstract}

Kata kunci: Prestasi belajar; Student Team Achievement Divisions.

\begin{abstract}
This study aims to determine the effectiveness of the Student Teams Achievement Division cooperative learning model in terms of mathematics achievement. This type of research is an experimental study with a population of eighth grade students of SMP N 3 Bantul taken using cluster random sampling technique. research instruments use tests on the subject matter of opportunity. data analysis techniques using t-test by considering the assumption test for the test. From the results of the study it can be concluded that on learning achievement, the Student Teams Achievement Division model is more effectively used in learning mathematics in the material opportunities when compared with the direct learning model. related to this result, the Student Teams Achievement Division Model can be used as an alternative in learning mathematics, especially in the material of probability.
\end{abstract}

Keywords: Achievement; Student Team Achievement Divisions.

\section{PENDAHULUAN}

Bagi masyarakat sekarang ini pendidikan sudah menjadi bagian yang penting dalam kehidupan mereka. Pendidikan sudah menjadi prioritas utama dalam kehidupan sehari-hari. Sudah banyak orang yang menyadari bahwa ilmu itu lebih penting daripada apapun. Dengan pandangan seperti itu pendidikan menjadi suatu yang mempunyai peranan penting dalam kehidupan (Setiyaningrum \& Istiqomah, 2015). Pendidikan merupakan usaha sadar dan terencana yang dilakukan manusia untuk mengembangkan potensi diri melalui kegiatan bimbingan, pengajaran, latihan keterampilan, dan pengalaman belajar yang berlangsung dari setelah seseorang dilahirkan sampai akhir hayat (Sudarsana, 2016).

Pembelajaran merupakan suatu proses yang rumit, tidak hanya sekedar guru menyampaikan materi tetapi guru memiliki tanggungjawab, mengarahkan dan menciptakan suasana untuk mendorong siswa dalam mengikuti pembelajaran. Kenyataan di lapangan, masih banyak siswa yang kurang tertarik pada pelajaran khususnya pelajaran matematika (Trizulfianto, 
Anggreini, \& Waluyo, 2017; Widodo, 2015). Matematika merupakan sebuah materi pelajaran yang dianggap sulit bagi sebagian besar siswa (Arindiono \& Ramadhani, 2013; Martyanti \& Suhartini, 2018; Widodo, 2015), matematika juga merupakan salah satu ilmu yang digunakan dalam setiap segi kehidupan bahkan menopang dari berbagai ilmu yang lain (Aisyah, Khasanah, Yuliani, \& Rohaeti, 2018; Citroresmi, Sugiatno, \& Suratman, 2016; Syahbana, 2012), sehingga dapat dikatakan bahwa matematika mempunyai peranan penting dalam kehidupan sehari-hari (Nugrawati, Nuryakin, \& Afrillianto, 2018; Widodo, 2013a). Dengan mempelajari matematika peserta didik dipersiapkan untuk dapat mengembangkan pemikiran yang kreatif dan inovatif dengan menggunakan bahasa yang matematis dan mudah dipahami (Astriwini, Marhaeni, \& Candiasa, 2014; Wiguna, Widiana, \& Sudana, 2016).

Dampak dari persepsi negatif ini, motivasi siswa dalam mempelajari matematika menjadi berkurang (Gani, 2016; Nur, 2016; Widodo, Laelasari, Sari, Nur, \& Putrianti, 2017). Secara umum dapat dinyatakan bahwa Dikarenakan motivasi siswa dalam mempelajari matematika tidak maksimal, maka kemampuan siswa dalam menyelesaikan soal matematika juga diperoleh yang kurang maksimal pula (Gunantara, Suarjana, \& Riastini, 2014; Mandur, Sadra, \& Suparta, 2001). Seperti hasil penelitian sebelumnya yang menunjukkan bahwa kemampuan siswa dalam memecahkan masalah matematis sangat rendah, prestasi belajar siswa masih ada yang dibawah ketuntasan minimal (Hertiavi, Langlang, \& Khanafiyah, 2010; Pardimin, Widodo, \& Purwaningsih, 2018; Widodo, 2013b, 2014). Begitu pula dengan siswa SMP Negeri 3 Bantul diperoleh bahwa rata rata prestasi belajar siswa pada pelajaran matematika sebesar 56.

Untuk meningkatkan kemampuan siswa dalam menyelesaikan soal Matematika, salah satu model pembelajaran yang dapat digunakan diantaranya adalah model pembelajaran kooperatif tipe Student Teams Achievement Division atau STAD (Balfakih, 2003; Esminarto, Sukowati, Suryowati, \& Anam, 2016; Wyk, 2012). Model STAD melibatkan peran siswa secara mandiri adalah model pembelajaran kooperatif (Dhewani, Yamtinah, \& Martini, 2015; Esminarto et al., 2016). Secara umum bahwa model ini dikembangkan untuk mencapai hasil belajar berupa prestasi akademik, toleransi, menerima keragaman, dan pengembangan keterampilan sosial (Widuri, Sujadi, \& Widodo, 2014).

Berdasarkan hal tersebut maka tujuan artikel ini adalah untuk mengetahui efektifitas model pembelajaran kooperatif tipe Student Teams Achievement Division (STAD) ditinjau dari prestasi belajar matematika. Prestasi belajar dalam penelitian ini adalah prestasi belajar pada ranah kognitif seperti yang diungkapkan oleh Suhendri bahwa salah satu aspek kognitif yang dapat diukur adalah prestasi belajar (Suhendri, 2011, 2013).

\section{METODE PENELITIAN}

Sesuai dengan permasalahan penelitian yang akan diteliti maka jenis penelitian yang digunakan adalah eksperimen. Penelitian ini bermaksud memberikan perlakuan pada sampel penelitian (Creswell, 2012a, 2012b). Dimana perlakuan yang diberikan adalah model pembelajaran STAD dan 
DOI: https://doi.org/10.24127/ajpm.v8i3.2312

model pembelajaran yang sering dilakukan di oleh guru yaitu model pembelajaran langsung (direct instruction). Selanjutnya ingin mengetahui keefektifan terhadap masing-masing perlakuan.

Penelitian ini dilaksanakan di SMP Negeri 3 Bantul. Sampel penelitian diambil menggunakan teknik cluster random sampling. Dengan menggunakan teknik ini terambil dua kelas 8 yaitu kelas $8 \mathrm{~A}$ dan $8 \mathrm{~B}$. Untuk kelas 8A dengan siswa sebanyak 29 orang diberikan model pembelajaran yang biasa dilakukan oleh guru, sedangkan kelas 8B dengan siswa sebanyak 29 orang diberikan pembelajaran model Student Teams Achievement Division.

Instrumen yang digunakan dalam penelitian ini adalah tes pada pokok bahasan peluang. Instrumen berbentuk pilihan ganda yang terdiri 20 soal dengan empat alternatif pilihan jawaban. Setiap jawaban yang benar diberikan skor 1 (satu) tetapi jika jawaban salah diberikan skor 0 (nol). Sebelum siswa diberikan tes prestasi belajar ini, terlebih dahulu tes divalidasi oleh guru Matematika dan dosen pendidikan matematika. Validasi dilakukan untuk melihat apakah soal yang diusun telah sesuai dengan materi peluang atau belum.

Untuk menguji hipotesis yang diajukan menggunakan uji-t, dengan mempertimbangkan asumsi pada uji ini. Adapun asumsi yang digunakan pada uji-t diantaranya adalah data prestasi belajar diambil dari populasi yang berdistribusi normal (sifat normalitas) dan populasi yang digunakan memiliki variansi yang sama (sifat homogenitas variansi) (Glass, Peckham, \& Sanders, 1972). Untuk hipotesis yang diajukan dalam penelitian ini adalah model pembelajaran STAD lebih efektif digunakan dibandingkan model pembelajaran langsung.

\section{HASIL PENELITIAN DAN PEMBAHASAN}

Data yang digunakan untuk penelitian berupa data yang berasal dari tes prestasi belajar. Pada kelompok eksperimen atau kelompok dengan menggunakan model pembelajaran STAD diperoleh rata-rata prestasi belajar sebesar 59,80, sedangkan pada kelompok kontrol atau kelompok dengan menggunakan model pembelajaran langsung diperoleh rata rata sebesar 42,94.

Sebelum dilakukan uji hipotesis dengan menggunakan uji-t, dilakukan terlebih dahulu uji asumsi untuk melihat normalitas dan homogenitas varians. Uji normalitas bertujuan untuk menunjukkan apakah subyek yang digunakan berasal dari populasi berdistribusi normal. Uji normalitas dapat menggunakan uji Liliefors (Budiyono, 2004). Untuk uji homogenitas varians bertujuan untuk melihat kelompok subyek yang digunakan dalam penelitian ini (kelompok control dan kelompok eksperimen) memiliki variansi yang sama. Uji homogenitas varians dapat menggunakan uji Bartlett (Budiyono, 2004)

Pada sifat normalitas, uji statistik yang digunakan uji Liliefors. Hasil perhitungan diperoleh bahwa $\mathrm{L}_{\text {hitung }}$ untuk kelompok eksperimen sebesar 0,069 dan $\mathrm{L}_{\text {hitung }}$ pada kelompok kontrol sebesar 0,107, dengan $\mathrm{L}_{\text {tabel }}$ sebesar 0,248. Dengan hasil ini maka sampel pada kelompok kontrol dan eksperimen berasal dari populasi yang berdistribusi normal.

Pada sifat homogenitas varians, uji statistik yang digunakan adalah uji Bartlett. Hasil perhitungan diperoleh 
bahwa $\chi_{\text {hitung }}^{2}=0,2144$ dan $\chi_{\text {tabel }}^{2}=$ 3,1504 . Dengan $0,2144<3,1504$, hal ini dapat disimpulkan bahwa sampel yang digunakan memiliki variansi yang sama.

Untuk menguji hipotesis yang diajukan digunakan uji-t (Healy, 2010). Uji hipotesis dilakukan terhadap hasil tes prestasi belajar matematika siswa kelas yang menggunakan model pembelajaran STAD dengan kelas yang menggunakan model pembelajaran langsung. Dari hasil perhitungan uji-t berkorelasi menunjukkan bahwa thitung sebesar 3,482 dengan $t_{\text {tabel }}$ sebesar 0,2045 . Hasil ini menunjukkan bahwa siswa dengan menggunakan model pembelajaran STAD dan model pembelajaran langsung memberikan efek (prestasi belajar) yang berbeda. Dengan melihat rata-rata tes prestasi belajar matematika siswa menggunakan STAD sebesar 59,80 dan dengan model pembelajaran langsung sebesar 42,94 dapat disimpulkan bahwa model pembelajaran STAD memberikan efek (prestasi belajar) yang lebih baik jika dibandingkan dengan model pembelajaran langsung.

Pada prestasi belajar Matematika pada pokok bahasan peluang, dengan menggunakan pembelajaran kooperatif tipe STAD memberikan efek yang lebih baik jika dibandingkankan menggunakan model pembelajaran langsung. Model pembelajaran ini melibatkan peran siswa secara mandiri adalah model pembelajaran kooperatif (Dhewani et al., 2015; Esminarto et al., 2016). Hal ini dikarenakan karakteristik model pembelajaran kooperatif diantaranya adalah siswa dibagi dalam tim belajar beranggotakan empat orang yang heterogen (Deutsch, 2011; Joni, 2013), Guru dapat memberdayakan siswa dalam proses pembelajaran sehingga dapat membantu kesulitan guru dalam mengatur jumlah siswa yang banyak (Zakaria, Solfitri, Daud, \& Abidin, 2013), selain itu karakteristik pada model ini adalah penggunaan kuiskuis secara individual pada tiap akhir pelajaran (Slavin, 1995). Artinya model pembelajaran ini memberikan ruang yang lebih bagi siswa untuk berfikir merespon dan bekerjasama dengan siswa lain.

Setiap proses pembelajaran dapat dipastikan siswa berharap untuk mendapatkan prestasi belajar yang baik dan memuaskan, sebab prestasi belajar yang baik dapat membantu peserta didik dalam mencapai tujuannya. Prestasi belajar yang baik hanya dicapai melalui proses belajar yang baik pula (Basuki, 2015). Siswa masih beranggapan pembelajaran matematika membosankan dan tidak menarik. Guru masih menggunakan model pembelajaran langsung sehingga siswa beranggapan bahwa guru akan memberitahukan pada siswa apa yang perlu mereka ketahui. Anggapan siswa seperti ini menyebabkan matematika menjadi sulit dan tidak menyenangkan sehingga pembelajaran terlihat lebih lama. Perhatian siswa yang teralihkan, siswa terlihat memperhatikan tetapi pada saat ujian hasilnya tidak memuaskan. Dari hal tersebut dimungkinkan prestasi belajar siswa pada pelajaran matematika menjadi menurun.

Berdasarkan hasil penelitian yang telah diperoleh maka model pembelajaran STAD menjadi lebih efektif jika dibandingkan dengan menggunakan model pembelajaran langsung, hal ini dikarenakan siswa dapat bekerjasama dengan siswa yang lain pada pembelajaran dengan menggunakan model STAD. Pemilihan model pembelajaran kooperatif tipe Student Teams Achievement Division (STAD) dimaksud agar siswa merubah 
DOI: https://doi.org/10.24127/ajpm.v8i3.2312

pola pikir bahwa pembelajaran matematika menjadi pelajaran yang menyenangkan dan tidak membosankan. Dengan model ini siswa diharapkan mengikuti kegiatan pembelajaran dengan baik akan berpengaruh pada keberhasilan kelompoknya. Model pembelajaran STAD tepat untuk dilaksanakan oleh beberapa guru yang baru saja menerapkan strategi pembelajaran kooperatif. Dalam hal ini, guru membimbing siswa dalam pembelajaran sehingga tercipta suasana belajar yang menyenangkan, aktif dan efektif.

\section{KESIMPULAN DAN SARAN}

Berdasarkan hasil dan pembahasan dapat disimpulkan bahwa pembelajaran Matematika pada materi peluang, dengan menggunakan model pembelajaran kooperatif tipe STAD lebih efektif digunakan jika dibandingkan dengan model pembelajaran langsung. Berkaitan dengan hasil ini dapat disarankan bahwa model pembelajaran STAD dapat digunakan sebagai alternatif dalam pembelajaran Matematika, sedangkan untuk peneliti selanjutnya dapat dilakukan penelitian lebih lanjut terkait dengan model STAD pada materi Matematika selain peluang.

\section{DAFTAR PUSTAKA}

Aisyah, P. N., Khasanah, S. U. N., Yuliani, A., \& Rohaeti, E. E. (2018). Analisis Kemampuan Pemecahan Masalah matematis siswa SMP pada Materi Segi Empat dan Segi Tiga. JPMI: Jurnal Pembelajaran Matematika Inovatif, 1(5), 77-83. https://doi.org/https://doi.org/10.52 81/zenodo.1405906
Arindiono, R. Y., \& Ramadhani, N. (2013). Perancangan Media Pembelajaran Interaktif Matematika Untuk Siswa Kelas 5 SD. Jurnal Sains Dan Seni Pomits, 2(1), 28-32.

Astriwini, N. B., Marhaeni, A. A. I. N., \& Candiasa, I. M. (2014). Pengaruh Model Pembelajaran Pemecahan Masalah Berbantuan Media Lingkungan Terhadap Hasil Belajar Matematika Siswa Kelas V SD Gugus VI Kecamatan Buleleng Ditinjau Dari Gaya Kognitif. EJournal Program Pascasarjana Universitas Pendidikan Ganesha, 4.

Balfakih, N. M. A. (2003). The effectiveness of student teamachievement division (STAD) for teaching high school chemistry in the United Arab Emirates. International Journal of Science Education.

https://doi.org/10.1080/095006901 10078879

Basuki, K. H. (2015). Pengaruh Kecerdasan Spiritual dan Motivasi Belajar terhadap Prestasi Belajar Matematika. Formatif: Jurnal Ilmiah Pendidikan MIPA. https://doi.org/10.30998/formatif.v $5 \mathrm{i} 2.332$

Budiyono. (2004). Statistika Untuk Penelitian. Solo: UNS Press.

Citroresmi, N., Sugiatno, \& Suratman, D. (2016). Pengembangan Modul Matematika Berbasis Masalah Untuk Meningkatkan Kemampuan Penyelesaian Masalah Dan Berpikir Kreatif Matematis Siswa. Jurnal Pendidikan Dan Pembelajaran, 5(4). 
DOI: https://doi.org/10.24127/ajpm.v8i3.2312

Creswell, J. W. (2012a). Educational Research: Planning, Conducting and Evaluating Quantitative and Qualitative Research. London: Pearson.

Creswell, J. W. (2012b). Research Design

Qualitative,Quantitative, and Mixed Second Edition.

Deutsch, M. (2011). Cooperation and Competition.

https://doi.org/10.1007/978-14419-9994-8

Dhewani, M. A., Yamtinah, S., \& Martini, K. S. (2015). Penerapan Model Pembelajaran Stad (Student Teams Achievement Division) Dilengkapi Dengan Lks Untuk Meningkatkan Motivasi Dan Prestasi Belajar Pada Materi Reaksi Kimia Siswa Kelas Vii Smp Negeri 19 Surakarta. Jurnal Pendidikan Kimia (JPK).

Esminarto, E., Sukowati, S., Suryowati, N., \& Anam, K. (2016). IMPLEMENTASI MODEL STAD DALAM MENINGKATKAN HASIL BELAJAR SIWA. Briliant: Jurnal Riset Dan Konseptual. https://doi.org/10.28926/briliant.v1 i1.2

Gani, A. (2016). PENGARUH MODEL PEMBELAJARAN DAN PERSEPSI TENTANG MATEMATIKA TERHADAP MINAT DAN HASIL BELAJAR MATEMATIKA SISWA SMP NEGERI DI KECAMATAN SALOMEKKO KABUPATEN BONE. Jurnal Daya Matematis. https://doi.org/10.26858/jds.v3i3.1 700
Glass, G. V, Peckham, P. D., \& Sanders, J. R. (1972). Consequences of Failure to Meet Assumptions Underlying the Fixed Effects Analyses of Variance and Covariance. Review of Educational Research, 42(3), 237-288. https://doi.org/10.3102/003465430 42003237

Healy, J. F. (2010). The Essential of Statistics: A Tool For Social Research. Canada: Wadsworth.

Hertiavi, M. A., Langlang, H., \& Khanafiyah, S. (2010). Penerapan Model Pembelajaran Kooperatif Tipe Jigsaw Untuk Peningkatan Kemampuan Pemecahan Masalah Siswa SMP. Jurnal Pendidikan Fisika Indonesia, 6(1). https://doi.org/10.15294/jpfi.v6i1.1 104

Joni, D. A. R. W. (2013). The effect of cooperative learning techniques on college students' reading comprehension. Jurnal Pendidikan Dan Pengajaran, 46(2), 155-162. https://doi.org/DOI 10.1016/j.system.2009.12.009

Martyanti, A., \& Suhartini. (2018). Etnomatematika: Menumbuhkan Kemampuan Berpikir Kritis Melalui Budaya. Indomath: Indonesia Mathematics Edcuation, 1(1), 35-41.

Nugrawati, U., Nuryakin, \& Afrillianto, M. (2018). Analisis Kesulitan Belajar Pada Kemampuan Komunikasi Matematis Siswa MTs Dengan Materi Segitiga Dan Segiempat. Indomath: Indonesia Mathematics Edcuation, 1(2), 6368. 
Nur, M. A. (2016). Pengaruh Perhatian Orang Tua, Konsep Diri, Persepsi Tentang Matematika Terhadap Hasil Belajar Matematika Melalui Motivasi Belajar Siswa Kelas VIII SMP Negeri Di Kecamatan Ujung Loe Kabupaten Bulukumba. Matematika Dan Pembelajaran.

Pardimin, Widodo, S. A., \& Purwaningsih, E. (2018). Analisis Butir Soal Tes Pemecahan Masalah Matematika. Wacana Akademika: Majalah Ilmiah Kependidikan, 1(1), 69-76.

Setiyaningrum, E., \& Istiqomah. (2015). Efektivitas Penerapan Model Pembelajaran Think - Talk - Write Terhadap Prestasi Belajar Matematika Siswa Kelas Vii Smp Negeri 3 Magelang. Union, 3(1), 9-16.

Slavin, R. E. (1995). Cooperative Learning: Theory, Research and Practice. New Jersey: Prentice Hall.

Sudarsana, I. K. (2016). PEMIKIRAN TOKOH PENDIDIKAN DALAM BUKU LIFELONG LEARNING: POLICIES, PRACTICES, AND PROGRAMS (Perspektif Peningkatan Mutu Pendidikan di Indonesia). Jurnal Penjaminan Mutu.

https://doi.org/10.25078/jpm.v2i2. 71

Suhendri, H. (2011). Pengaruh Kecerdasan Matematis-Logis dan Kemandirian Belajar terhadap Hasil Belajar Matematika. Formatif: Jurnal Ilmiah Pendidikan MIPA. https://doi.org/10.30998/formatif.v $1 \mathrm{i} 1.61$
Suhendri, H. (2013). Pengaruh metode pembelajaran problem solving terhadap hasil belajar matematika ditinjau dari kemandirian belajar. Formatif: Jurnal Ilmiah Pendidikan MIPA, 3(2), 105-114. Retrieved from http://journal.lppmunindra.ac.id/in dex.php/Formatif/article/view/117/ 114

Syahbana, A. (2012). Peningkatan Kemampuan Berpikir Kritis Matematis Siswa SMP Melalui Pendekatan Contextual Teaching And Learning. EDUMATICA| Jurnal Pendidikan Matematika, 2(1), 45-57.

Trizulfianto, T., Anggreini, D., \& Waluyo, A. (2017). ANALISIS KESULITAN SISWA DALAM MEMECAHKAN MASALAH MATEMATIKA MATERI PROGRAM LINIER BERDASARKAN GAYA BELAJAR SISWA. UNION: Jurnal Ilmiah Pendidikan Matematika.

https://doi.org/10.30738/.v5i2.1229

Widodo, S. A. (2013a). Implementasi Team Teaching Terhadap Prestasi Belajar Siswa SMA Kelas X SeKota Yogyakarta Pada Materi Trigonometri. Union: Jurnal Pendidikan MAtematika, 1(1), 4350.

Widodo, S. A. (2013b). Proses Berpikir Mahasiswa Dimensi Supervisor Dalam Menyelesaikan Masalah Divergensi. In Prosiding SNMPM Universitas Sebelas MAret (Vol. 1, pp. 293-300). Surakarta: UNS.

Widodo, S. A. (2014). Ekperimentasi Pembelajaran CPS Ditinjau Dari Kemampuan Awal Terhadap 
DOI: https://doi.org/10.24127/ajpm.v8i3.2312

Prestasi Belajar Interpolasi. Jurnal Pendidikan Progresif, 4(1).

Widodo, S. A. (2015). Keefektivan Team Accelerated Instruction Terhadap Kemampuan Pemecahan Masalah dan Prestasi Belajar Matematika Siswa Kelas VIII. Kreano, Jurnal Matematika Kreatif-Inovatif, 6(2), 127-134.

Widodo, S. A., Laelasari, Sari, R. M., Nur, I. R. D., \& Putrianti, F. G. (2017). Analisis faktor tingkat kecemasan, motivasi dan prestasi belajar mahasiswa. Jurnal Taman Cendekia, 01(01), 67-77.

Widuri, A., Sujadi, A. A., \& Widodo, S. A. (2014). Experimentation STAD With CTL To Material Of Phytagoras Teorema Was Inspected From The Temperament Of Student In Class VIII SMP N 3 Pengasih Kulon Progo The Academic Year 2013/2014. In Proceeding of International Conference On Research, Implementation And Education Of Mathematics And Sciences (pp. 18-20). Yogyakarta: Universitas Negeri Yogyakarta.

Wiguna, S. G. A., Widiana, I. W., \& Sudana, D. N. (2016). Penerapan Pembelajaran Berbasis Otak Untuk Meningkatkan Kemampuan Pemecahan Masalah Matematika Siswa Kelas V Sekolah Dasar. Mimbar PGSD Undiksha, 4(1), 111.
Wyk, M. M. van. (2012). The Effects of the STAD-Cooperative Learning Method on Student Achievement, Attitude and Motivation in Economics Education. Journal of Social Sciences. https://doi.org/10.1080/09718923.2 012.11893104

Zakaria, E., Solfitri, T., Daud, Y., \& Abidin, Z. Z. (2013). Effect of Cooperative Learning on Secondary School Students , Mathematics Achievement. Creative Education, 4(2), 98-100. 